\title{
Wilkie's syndrome
}

\author{
Renato Farina $^{1}$ (i) Pietro Valerio Foti ${ }^{1} \cdot$ Giuseppe Cocuzza $^{1} \cdot$ Valeria Costanzo $^{1}$. \\ Giuliana Costanzo $^{1} \cdot$ Alessandro Conti $^{1} \cdot$ Alfredo Torcitto $^{1} \cdot$ Monica Pennisi $^{1}$
}

Received: 2 May 2017/Accepted: 31 May 2017/Published online: 3 August 2017

(C) Società Italiana di Ultrasonologia in Medicina e Biologia (SIUMB) 2017

\begin{abstract}
Superior mesenteric artery syndrome, also known as Wilkie's syndrome, is a rare vascular disease caused by the anomalous course of the superior mesenteric artery arising from the abdominal aorta with a smaller angle than the norm $\left(<22^{\circ}\right)$. The reduced angle compresses the structures situated between the aorta and the superior mesenteric artery, such as the duodenum and left renal vein; this can determine painful crises, intestinal subocclusions, and left varicocele. This syndrome can be congenital or acquired. The acquired type is more common and is generally caused by reduced perivascular fat surrounding the abdominal aorta and the superior mesenteric artery; this form is common among anorexic patients that have had a rapid weight loss. We present the case of a female patient who suffered from repeated postprandial vomiting and who lost $12 \mathrm{~kg}$ in 4 months. B-mode ultrasound imaging revealed evidence of a reduced angle between the aorta and the superior mesenteric artery, as found in Wilkie's syndrome. After diagnosis, the patient followed a high-calorie diet, and 2 months later an ultrasound scan proved the restoration of the aorto-mesenteric angle as a consequence of increased perivascular fat with regression of symptoms.
\end{abstract}

Keywords Ultrasound - Wilkie's syndrome · Superior mesenteric artery

Sommario La sindrome dell' arteria mesenterica superiore o sindrome di Wilkie è una patologia vascolare rara dovuta

Renato Farina

radfaro@hotmail.com

1 Radiodiagnostic and Radiotherapy, University Hospital "Policlinico-Vittorio Emanuele", Via Santa Sofia 78, 95123 Catania, Italy all'anomalo decorso dell' arteria mesenterica superiore che nasce dall'aorta addominale con un angolo ridotto rispetto alla norma (inferiore a $22^{\circ}$ ). L'angolazione ridotta provoca la compressione delle strutture che passano tra l'aorta e l'arteria mesenterica superiore, il duodeno e la vena renale sinistra; questo può determinare crisi dolorose, sub-occlusioni intestinali e varicocele sinistro. Questa sindrome può essere congenita o acquisita. La forma acquisita, più frequente, è dovuta in genere alla riduzione del pannicolo adiposo peri-vascolare che circonda l'aorta addominale e l'arteria mesenterica superiore; questa forma è comune soprattutto nei pazienti anoressici che hanno subito una rapida perdita di peso. Presentiamo un caso di una paziente affetta da crisi ripetute di vomito post-prandiale che ha subito una perdita di $12 \mathrm{~kg}$ in 4 mesi. Durante l'esame ecografico B-Mode si evidenziava una riduzione dell'angolo tra aorta ed arteria mesenterica superiore, tipico della sindrome di Wilkie. Successivamente la paziente ha eseguito una dieta ipercalorica e dopo due mesi l'ecografia dimostrava il ripristino dell'angolo aorto-mesenterico come conseguenza dell'aumento del grasso peri-vascolare con regressione dei sintomi.

\section{Introduction}

Superior mesenteric artery syndrome, also known as Wilkie's syndrome [1-6], is a rare vascular disease with a variable incidence from $0.2 \%$ [7] to $0.78 \%$ [8], and it occurs mostly in women. It is due to the anomalous course of the superior mesenteric artery that originates from the abdominal aorta with an angle less than $22^{\circ}$ [9]. In Wilkie's syndrome, the reduced aorto-mesenteric angle compresses the structures that are situated between the aorta and the 
Fig. 1 Ultrasound examination before treatment: longitudinal subxiphoidal scan of the abdominal aorta. a The aortomesenteric angle is $15^{\circ}$. b The thickness of the perivascular fat (arrow) appears reduced. $A O$ abdominal aorta, $L$ liver, SMA superior mesenteric artery
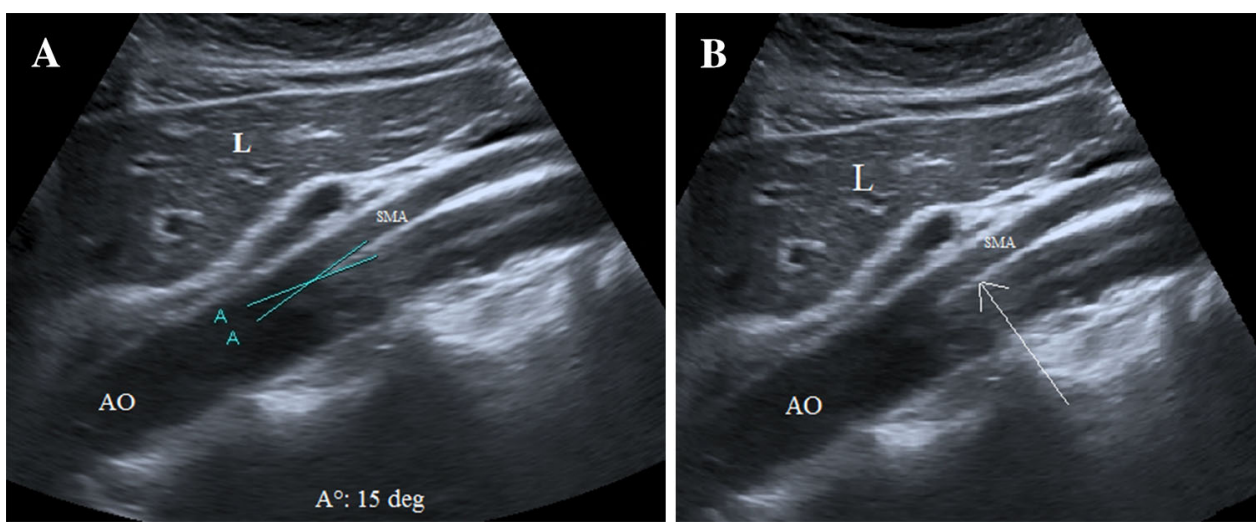

superior mesenteric artery, such as the third portion of duodenum and the left renal vein. As a consequence, patients can have symptoms such as painful crises, postprandial vomiting [10], and/or left varicocele due to venous congestion in the left renal and spermatic or gonadic veins [11].

This syndrome can be congenital or acquired. The congenital type is less frequent and its symptoms are already present in childhood. In the acquired type, the reduction of the aorto-mesenteric angle is caused by a decrease in the perivascular fat that surrounds the abdominal aorta and the superior mesenteric artery (especially in anorexic patients). After diagnosis, the patient generally follows a high-calorie diet to increase the perivascular adipose tissue; if this therapy fails, the patient undergoes surgery to remove the duodenal compression.

The diagnosis can be made by measuring the aortomesenteric angle with ultrasonography.

The coexistence of an angle less than $22^{\circ}$ and a varicocele and/or a compression of the third portion of duodenum allow us to make the diagnosis.

\section{Case report}

The 54-year-old female patient would vomit after ingesting solid and liquid food and had lost $12 \mathrm{~kg}$ in 4 months. She underwent a B-mode ultrasound longitudinal scan of the subxiphoidal region, in supine position, to study the abdominal aorta and superior mesenteric artery. An Aplio XG device (Toshiba) and an ultrasound convex probe (3.5 MHz) were used. The ultrasound exam was performed by an experienced operator.

The exam showed a reduction of the aorto-mesenteric angle $\left(15^{\circ}\right)$, measured at about $1 \mathrm{~cm}$ from the bifurcation, and a consequent decrease of the perivascular fat that surrounds the abdominal aorta and the superior mesenteric artery (diameter $2 \mathrm{~mm}$ ) (Fig. 1a, b).

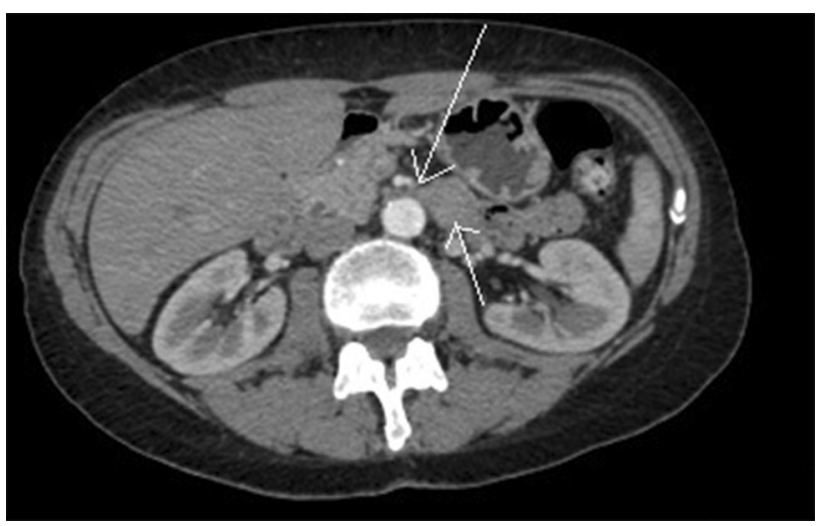

Fig. 2 CT: the axial scanning proves the constriction of the aortomesenteric angle (long arrow) and the compression of the third portion of the duodenum (short arrow)

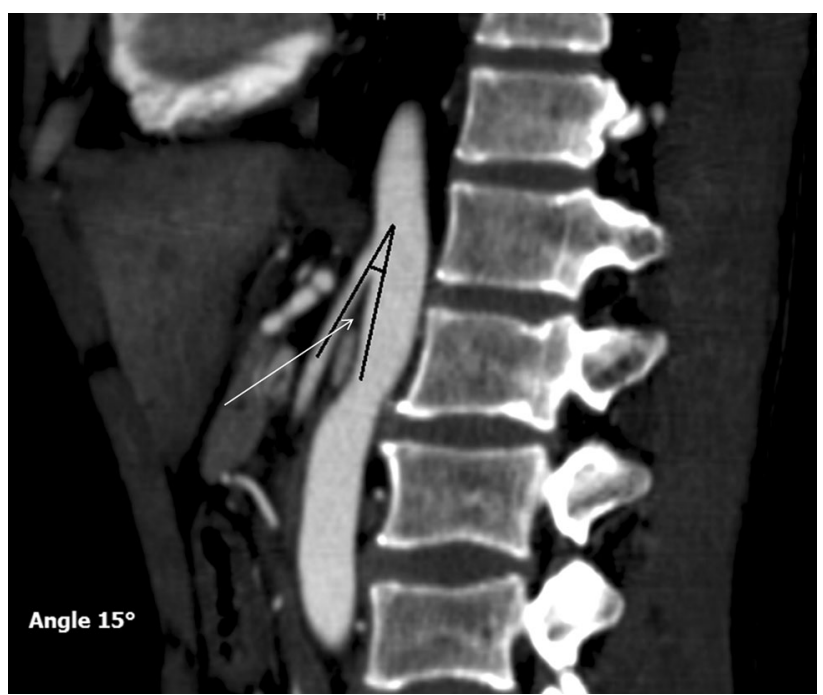

Fig. 3 CT: the sagittal reconstruction shows the reduction of the aorto-mesenteric angle with "beak sign" (arrow)

Afterwards, the patient had an abdominal CT examination that confirmed both the aorto-mesenteric angle's decrease and the compression of the third portion of the 


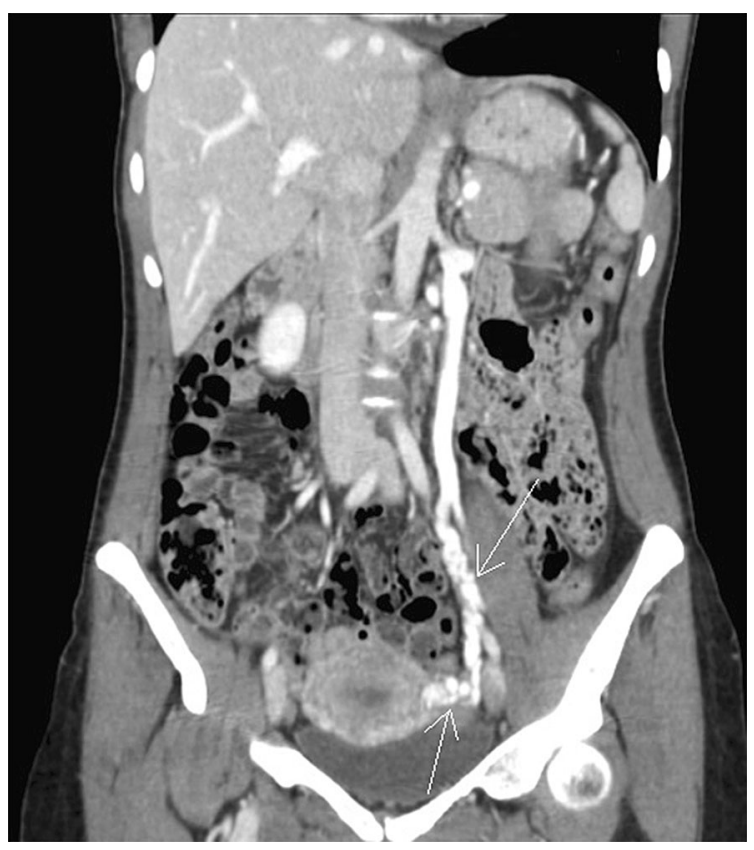

Fig. 4 Reconstruction CT coronal that shows left pelvic varicocele (arrows)

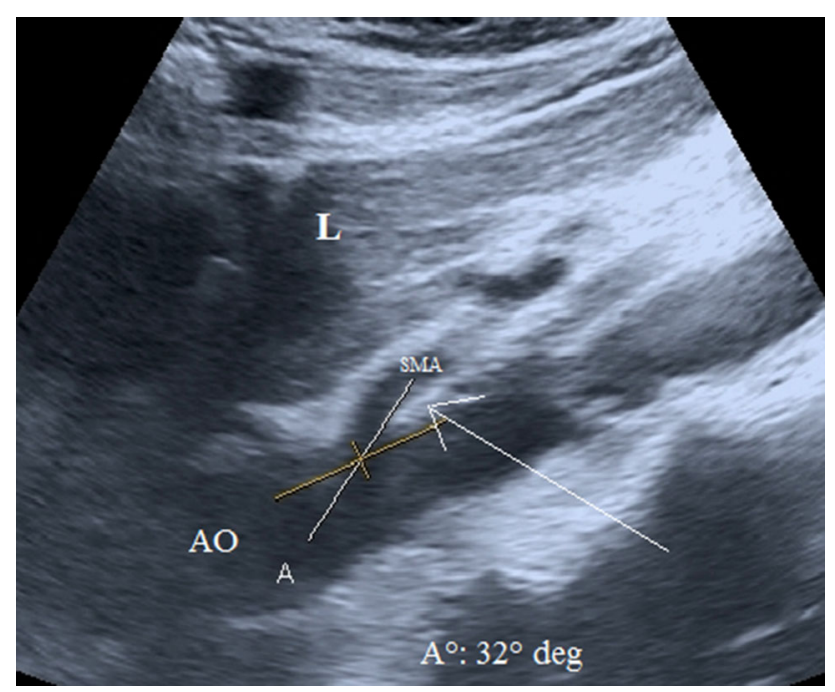

Fig. 5 Ultrasound examination after the treatment: longitudinal subxiphoidal scan of the abdominal aorta. The aorto-mesenteric angle (A) is $32^{\circ}$. The ultrasound scan shows increased thickness of the perivascular fat (arrow). AO abdominal aorta, $L$ liver, SMA superior mesenteric artery

duodenum (Fig. 2), with the characteristic "beak sign" in sagittal reconstruction (Fig. 3); pelvic varicocele was also present (Fig. 4). The patient followed a high-calorie diet, and 2 months later, after the disappearance of emetic symptoms, another ultrasound scan proved a $32^{\circ}$ aorto-mesenteric angle and an increase of the adipose tissue's thickness (diameter $8 \mathrm{~mm}$ ) (Fig. 5).

\section{Discussion}

Wilkie's syndrome is common in anorexic patients and is associated with emetic symptoms and reduced perivascular adipose tissue. Vomiting is initially self-induced, and it becomes organic as a consequence of the reduction of the aorto-mesenteric angle. The ultrasound is a very sensitive method that shows a high correlation with CT [7]: it can easily and accurately prove the decrease of the aorto-mesenteric angle, and it can also reveal the presence of varicocele (caused by the compression of the left renal vein). The $\mathrm{CT}$ or a contrastographic traditional examination can demonstrate the compression of the third portion of duodenum, which is responsible for the pain and emetic symptoms $[12,13]$. In these patients, the first therapeutic approach is represented, as in our case, by a high-calorie diet; alternatively, they must undergo a complicated surgery to remove the duodenal compression.

\section{Compliance with ethical standards}

Conflict of interest The authors declare that they have no conflict of interest.

Ethical approval All procedures performed in studies involving human participants were in accordance with the ethical standards of the institutional and/or national research committee and with the 1964 Helsinki declaration and its later amendments or comparable ethical standards.

Informed consent Informed consent was obtained from all individuals participating in the study.

\section{References}

1. Wilkie DPD (1927) Chronic duodenal ileus. Am J Med Sci 173:643

2. Kwan E (2004) Wilkie's syndrome. Surgery 135(2):225-227

3. Gthrie RH Jr (1971) Wilkie's syndrome. Ann Surg 173(2):290-293

4. Fong JK, Poh AC, Tan AG et al (2014) Imaging findings and clinical features of abdominal vascular compression syndromes. Am J Roentgenol 203:29-36

5. Gebhart T (2015) Superior mesenteric artery syndrome. Gastroenterol Nurs 38:189-193

6. Gulleroglu K, Gulleroglu B, Baskin Baskin (2014) Nutcracker syndrome. World J Nephrol 3:277-281

7. Unal B, Aktas A, Kemal G et al (2005) Superior mesenteric artery syndrome; CT and ultrasonography findings. Diagn Interv Radiol 11(2):90-95

8. Agrawal GA, Johnson PT, Fisherman EK (2007) Multidetector row CT of superior mesenteric artery syndrome. J Clin Gastroenterol 41(1):62-65

9. Welsch T, Büchler MW, Kienle P (2007) Recalling superior mesenteric artery syndrome. Dig Surg 24:149-156

10. Baltazar U, Dunn J, Floresguerra C et al (2000) Superior mesenteric artery syndrome: an uncommon cause of intestinal obstruction. South Med J 93(6):606-608 
11. Inal M, Karadeniz Biligili MY, Sahin S (2014) Nutcracker syndrome accompanying pelvic congestion syndrome; color doppler sonography and multislice CT findings: a case report. Iran $\mathbf{J}$ Radiol 11:11075

12. Biank V, Werlin S (2006) Superior mesenteric artery syndrome in children: a 20-year experience. J Pediatr Gastroenterol Nutr 42(5):522-525
13. Ylinen P, Kinnunen J, Hockerstedt K (1989) Superior mesenteric artery syndrome. A follow-up study of 16 operated patients. J Clin Gastroenterol 11(4):386-391 